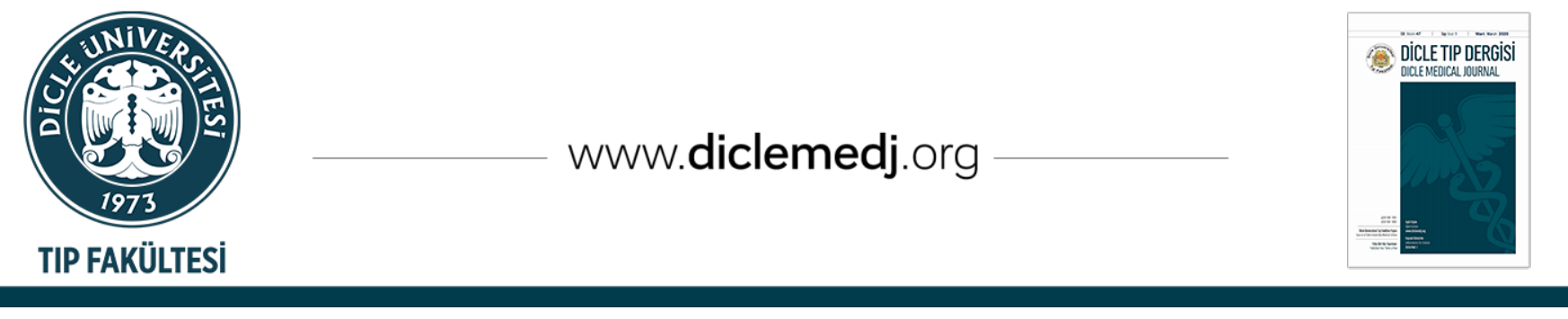

Original Article / Özgün Araştırma

\title{
Psychological Stress of Healthcare Workers Caused by the COVID-19 Pandemic
}

\author{
Gülşen Yalçın ${ }^{D}$ 1, Bahattin Sayınbatur ${ }^{\text {iD }}$ 2, Eyaz Karay ${ }^{\text {iD }}$, Merve Karakaş iD 4 \\ 1 Pediatric Emergency Specialist Diyarbakır Pediatric Diseases Hospital, Diyarbakır, Turkey \\ 2 Pediatric Neurology Specialist Diyarbakır Pediatric Diseases Hospital, Diyarbakır, Turkey \\ 3 Child Psychiatry Diyarbakır Pediatric Diseases Hospital, Diyarbakır, Turkey \\ 4 Research nurse Diyarbakır Pediatric Diseases Hospital, Diyarbakır, Turkey
}

Received: 29.06.2020; Revised: 19.08.2020; Accepted: 30.08.2020

\begin{abstract}
Objective: The study was aimed to evaluate the psychological stress of hospital workers and related factors during the period of Coronavirus disease-2019 (COVID-19) pandemic.

Methods: A survey was conducted among hospital workers between March 23 and April 1, 2020. The survey had four sections in total, including consent form, sociodemographic form, Turkish Impact of Events Scale, and depression, anxiety, and stress scale.

Results: The mean age of 257 respondents was $36.7 \pm 9.1(20-61)$ years, and $145(56.4 \%)$ of them were male. Post-traumatic stress disorder symptom level, depression, anxiety, and stress were significantly higher in women than in men [(\%95Cl, 1.09-3.73; $\mathrm{p}=0.026)$, (\%95Cl, 1.61-5.47; p=0.001), (\%95Cl, 1.23-3.97; $\mathrm{p}=0.008),(\% 95 \mathrm{Cl}, 1.36-4.86 ; \mathrm{p}=0.004)$, respectively]. Post-traumatic stress disorder symptom level rates of emergency room workers were significantly higher than those of the workers in other departments $(\% 95 \mathrm{Cl}$, 1.25-4.91; $\mathrm{p}=0.010$ ). According to those who stated that the infection measures taken in the hospital were insufficient, the rates of depression, anxiety and stress was significantly higher than those who stated that they were sufficient $[(95 \% \mathrm{Cl}, 1.51-7.18$; $\mathrm{p}=0.003)$, (95\% Cl, 1.23-5.23; $\mathrm{p}=0.011),(95 \% \mathrm{Cl}, 1.47-8.18 ; \mathrm{p}=0.004)$, respectively]. The rate of depression, anxiety, and stress was significantly higher in employees who previously had psychiatric disease than those who did not have disease before $[(95 \% \mathrm{Cl}, 1.37-160.7$; $\mathrm{p}=0.026)$, (95\% Cl, 1.20-128.3; p=0.035), (\% $95 \mathrm{Cl}, 1.01-47.36, \mathrm{p}=0.049)$, respectively].
\end{abstract}

Conclusions: In the present study, we found that the mental health of hospital workers was affected during the COVID-19 pandemic, and there was a difference between departments. More psychological stress occurs in specific groups such as emergency services and female healthcare professionals, and these groups should primarily be provided with psychological support.

Keywords: COVID-19, Healthcare workers, Psychological status.

\section{DOI: 10.5798/dicletip.799626}

Correspondence / Yazışma Adresi: Gülșen Yalçın, Diyarbakır Pediatric Diseases Hospital, Diyarbakır, Turkey e-mail: drgyalcin@gmail.com 


\section{COVID-19 Salgınının Neden Olduğu Sağlık Çalışanlarının Psikolojik Stresi}

Öz

Amaç: Bu çalışma, Coronavirus hastalığı-2019 (COVID-19) salgını döneminde hastane çalışanlarının psikolojik stresini ve ilişkili faktörleri değerlendirmeyi amaçlamıştır.

Yöntemler: Hastane çalışanlarına 23-Mart/1-Nisan 2020 tarihlerinde anket uygulama çalışması yapıldı. Anket; Onam formu, sosyodemografik form, Türkçe olayların etkisi ölçeği, depresyon, anksiyete ve stres ölçeği olmak üzere toplam 4 bölümdü.

Bulgular: Ankete katılan 257 kişinin yaş ortalaması 36,7 9,1yıl (20-61 arası) olup \%56,4'ü erkekti. Kadınlarda post-travmatik stres bozukluğu belirti düzeyi, depresyon, anksiyete, stress erkeklere oranla anlamlı düzeyde yüksek saptandı [(Cl\%95, 1,093,73; p=0,026), (Cl\%95, 1,61-5,47; p=0,001), (Cl\% 95, 1,23-3,97; p=0,008), (Cl\%95, 1,36-4,86; p=0,004), sirasiyla]. Acil servis çalışanlarının post travmatik stres bozukluğu belirti düzey oranları, diğer bölümlerde çalışanlara göre anlamlı derecede yüksekti (Cl\%95, 1,25-4,91; p=0,010). Hastanede alınan enfeksiyon önlemlerinin yetersiz olduğunu söyleyen çalışanlarda, yeterli olduğunu belirtenlere göre depresyon, anksiyete, stres oranı anlamlı düzeyde yüksekti $[(\mathrm{Cl} \% 95,1,51-7,18$; $\mathrm{p}=0,003),(\mathrm{Cl} \% 95,1,23-5,23 ; \mathrm{p}=0,011),(\mathrm{Cl} \% 95,1,47-8,18 ; \mathrm{p}=0,004)$, srasıyla]. Önceden psikiyatri hastalı̆̆ı olan çalışanlarda, önceden hastalığı olmayanlara göre depresyon, anksiyete, stres oranı anlamlı düzeyde yüksekti [(Cl\%95, 1,37-160,7; p=0,026), (Cl\%95, 1,20-128,3; p=0,035), (Cl\%95, 1,01-47,36, p=0,049), sirasiyla].

Tartışma: Çalıșmamızda COVID-19 salgını döneminde hastane çalıșanlarının ruhsal sağlığının etkilendiğini ve bölümler arasında fark olduğunu saptadık. Acil servis ve bayan sağlık çalıșanları gibi spesifik gruplarda daha fazla psikolojik stres oluşmakta olup bu gruplara öncelikle psikolojik destek sunmak gerekir.

Anahtar kelimeler: COVID-19, Sağlık çalışanları, Psikolojik durum.

\section{INTRODUCTION}

Coronavirus disease 2019 (COVID-19) is a global health threat that has caught the world off-guard. The World Health Organization (WHO) declared the COVID-19 pandemic a global health emergency on January 30, 20201. During infectious pandemics, people are affected by a wide range of psychosocial factors such as feelings of falling sick, death, and helplessness ${ }^{2}$. There are similar concerns among healthcare workers who undertake treatment and care of COVID-19 patients. In this critical situation, hospital workers directly involved in the diagnosis, treatment, and care of COVID-19 patients are at risk of psychological distress and other mental health disorders. An increasing number of cases, work overload, and issues such as lack of personal protective equipment and inadequate drugs increase the psychological burden on the workers. Healthcare workers are not only concerned about getting infected because of insufficient personal protective equipment and long working hours but also about the risk of infecting their families ${ }^{3,4}$. During the pandemic, healthcare workers feel stigmatized and consider resigning 5 . Infectious disease pandemics cause severe depression, anxiety, and stress, as well as long-term psychological effects on healthcare workers ${ }^{6}$. Many hospitals and healthcare systems recognize the stress on the workers and ensure provision of services by specialized consultants 7 . The first COVID-19 case in Turkey was detected on March 11, 2020. Starting from this date, the Ministry of Health rapidly set strategies to fight the pandemic using WHO recommendations ${ }^{8}$. Pandemic departments and teams were created in hospitals throughout Turkey. The Republic of Turkey Ministry of Health established Psychosocial Support Lines to reduce adverse psychological conditions and to prevent psychological diseases caused by the pandemic across the country. Support units were established within hospitals for healthcare workers with heavy workloads. 
This study evaluated the psychological stress results among hospital healthcare workers who have been in contact with COVID-19 patients.

\section{METHODS}

\section{Participants}

This prospective study was conducted in Diyarbakır Pediatric Diseases Hospital, Turkey. The research population consists of 1100 people working in Diyarbakır Pediatric Hospital. Hospital staffs are classified as healthcare workers (doctor, nurse, health technician), and non-health worker (administrative staff, automation, security, cleaning). A cross-sectional study was conducted in hospital workers using a questionnaire for psychological evaluation during the COVID-19 pandemic. Those who did not fully answer the questionnaire, those who were on leave and those who did not sign the consent form were excluded from the study. Those who completed all the questions of the questionnaire and gave their consent were included in the study. Procedure

Ethical approval for the study was obtained from the Republic of Turkey Ministry of Health General Directorate of Health Services and Health Sciences University Diyarbakır Gazi Yaşargil Training and Research Hospital (472. 05/15/2020). Informed consent was obtained from all participants. Data were collected within 10 days (March 23-April 01, 2020).

\section{Data collection tools}

Scales such as Impact of Events Scale and Depression Anxiety Stress Scales (DASS) have been used in studies associated with psychological stress of healthcare workers caused by the COVID-19 pandemic ${ }^{9-11}$.

Data collection form to be presented to the participants within the scope of this study consisted of four parts including consent form, sociodemographic form, Turkish Impact of Events Scale (TIES), and DASS-42.
1. The participants were asked about their sociodemographic data, age, gender, education level, marital status, number of children, place of residence, department of employment, number of people living with them, smoking, alcohol and substance abuse, chronic disease, or whether they have previously received treatment for psychiatric disease. They were also asked whether they have stayed in a guesthouse, considered resigning during this period, and whether the measures in the hospital were adequate.

2. TIES were used. The scale is a scale that aims to examine possible stress disorders in 1997 and after trauma by Weiss and Marmar and the cut-off score of the scale was $>33.12$ The validity and reliability study of the Turkish version of the scale was conducted.13 For determining the reliability of the TIES, an internal reliability analysis was performed, and the Cronbach's alpha coefficient was found to be 0.94 for the entire group. The cut-off score of the scale was set to 24-33 points. This scale aims to determine the stress level of subjects experiencing any trauma when using the scale. In the scale, there are 22 questions, in which the severity of the symptoms in the last 7 days is rated from 0 to 4 . Responses are given as (0) none, (1) mild, (2) moderate, (3) severe, and (4) very severe. The total score of the scale ranges from 0 to 88. A high score indicates a high level of post-traumatic stress disorder (PTSD) symptom level. According to TIES, a score of less than 23 points was considered as negative for PTSD, 24-33 points was considered as mild, and 34 points and above was considered as severe PTSD.

3. DASS-42 was used to study depression, anxiety, and stress levels. DASS-42 consists of 42 items, including 14 items on depression, 14 items on anxiety, and 14 items on stress. Depression items are measured by the questions numbered $(3,5,10,13,16,17,21,24$, $26,31,34,37,38$, and 42 ), anxiety items are 
measured by the questions numbered $(2,4,7,9$, $15,19,20,23,25,28,30,36,40$, and 41), and stress items are measured by the questions numbered $(1,6,8,11,12,14,18,22,27,29,32$, 33,35 , and 39). It is a four-digit scale, and the items are evaluated from 0 to 3 . The total scores of the scale range from 0 to 42 for each subdimension. The original form of the scale to be used in the study was developed as the Depression Anxiety Stress Scale (DASS-42) by Lovibond and Lovibond in 199514. In the original study, the internal consistency coefficients (Cronbach's Alpha) of the scale for depression, anxiety, and stress dimensions were found as $0.91,0.84$, and 0.90 , respectively. Regarding reliability of the Turkish version of the scale, the Cronbach's alpha coefficients were calculated to be 0.92 for depression, 0.86 for anxiety, and 0.88 for stress for the internal consistency of the scale.In the Turkish version of the scale, the cut-off score was 10 for depression, 7 for anxiety, and 14 for stress ${ }^{15}$. In terms of depression, a score of 0-10 points was considered healthy, that of $11-13$ points was considered mild, that of $14-20$ points was considered moderate, that of 21-27 points was considered severe, and that of 28 points and above was considered very severe. It is believed that those who score 0-7 points in terms of anxiety are healthy. In terms of anxiety, a score of 8-9 points was considered mild, that of 1014 points was considered moderate, that of $15-$ 19 points was considered severe, and that of 20 points and above was considered very severe. In terms of stress, those who scored between 0 and 14 were considered healthy, whereas those who scored 15-18 points were considered to have mild, $19-25$ points were considered to have moderate, 26-33 points were considered to have severe, and 34 points were considered to have very severe stress.

The questionnaires were filled in by the participants with their written consents. The results of the questionnaire were evaluated by the psychiatrist. However, no psychiatric interview was provided with any participant.

\section{Statistical Analysis}

Individuals included in the sample were selected from among the employees of Diyarbakır Pediatric Diseases Hospital. Altogether, 268 individuals who voluntarily participated in the study were included using purposeful sampling. Eleven individuals were not included in the study because they filled out the survey form incompletely. Data were entered into the SPSS 15.0 program. Frequency distributions and means of data were found. The scales (TIES and DASS) were grouped according to their cut-off points. Chi-squared and Fischer's exact tests were used for the comparison of categorical data. Subsequently, binary logistic regression analysis was performed to determine the risk factors. $\mathrm{P}<0.05$ was considered statistically significant.

For logistic regression analysis: Risk factors were evaluated by classifying 23 cut-off values and the assessment as $<23$ and $\geq 24$ for PTSD symptom level. Similarly in DASS-42; Risk factors were evaluated by classifying the assessment as $<10$ ve $\geq 11$ for depression, $<7$ and $\geq 8$ for anxiety, and $<14$ and $\geq 15$ for stress.

Group sample sizes of 112 and 145 achieve 99\% power to detect a difference of 8,8 between the null hypothesis that both group means are 31,7 and the alternative hypothesis that the mean of group 2 is 22,9 with estimated group standard deviations of 18,0 and 14,4 and with a significance level (alpha) of 0,05000 using a two-sided two-sample t-test.

\section{RESULTS}

A total of 257 individuals participated in the survey. Their mean age was 36.7 9.1 (20-61) years, and $145(56.4 \%)$ of them were males. Approximately $62(24.1 \%)$ of the respondents had studied until high school or below and 195(75.9\%) were university graduates. 
Approximately $170(66.1 \%)$ of the respondents were married, and $155(60.3 \%)$ had children. Nearly $82(31.9 \%)$ of the employees were working in clinics and outpatient clinics, $56(21.8 \%)$ in the emergency room, $57(22.2 \%)$ in intensive care, and 62(24.1\%) in the administration. Among the respondents, 95(37.0\%) were nurses and 52(20.2\%) were doctors; in addition, $84(32.7 \%)$ of the workers were smokers and 15(5.8\%) drank alcohol. Furthermore, $42(16.3 \%)$ of the respondents had a chronic disease (diabetes mellitus, hypertension, and chronic renal failure), $6(2.3 \%)$ were previously treated for a psychiatric disease (depression), and 5(1.9\%) received psychiatric treatment due to the pandemic. Among the respondents, 17(6.6\%) were living in a guest house during the pandemic and 18(7.0\%) had considered resigning. Approximately $68(26.5 \%)$ of the respondents stated that the measures taken in the hospital were adequate, $117(45.5 \%)$ were partially adequate and $72(28.0 \%)$ stated that they were inadequate (Table I).

According to TIES, PTSD symptom level was not present in 116 (45.1\%), mild in 63(24.5\%), and severe in $78(30.4 \%)$ of the respondents. According to DASS-42, there was no depression in $171(66.5 \%$ of the respondents, mild depression in $26(10.1 \%)$, moderate depression in $36(14 \%)$, severe depression in $11(4.3 \%)$, and very severe depression in $13(5.1 \%)$ of the respondents. Anxiety was absent in $167(65.0 \%)$, mild in $23(8.9 \%)$, moderate in $29(11.3 \%)$, severe in $19(7.4 \%)$, and very severe in $19(7.4 \%)$ of the respondents. Stress was absent in $167(73.2 \%)$, mild in $25(9.7 \%)$, moderate in $25(9.7 \%)$, severe in $12(4.7 \%)$, and very severe in $7(2.7 \%)$ of the respondents (Figure 1).
Table I: Demographic characteristics of the respondents.

\begin{tabular}{|c|c|c|}
\hline & Number & $\%$ \\
\hline $\begin{array}{l}\text { Age groups } \\
29 \text { y and under } \\
30-39 \text { y } \\
40 \text { y and older }\end{array}$ & $\begin{array}{c}64 \\
101 \\
92 \\
\end{array}$ & $\begin{array}{l}24.9 \\
39.3 \\
35.8 \\
\end{array}$ \\
\hline \begin{tabular}{|l|} 
Gender \\
Male \\
Female \\
\end{tabular} & $\begin{array}{l}145 \\
112\end{array}$ & $\begin{array}{l}56.4 \\
43.6\end{array}$ \\
\hline $\begin{array}{l}\text { Education } \\
\text { High school and below } \\
\text { University }\end{array}$ & $\begin{array}{c}62 \\
195 \\
\end{array}$ & $\begin{array}{l}24.1 \\
75.9 \\
\end{array}$ \\
\hline $\begin{array}{l}\text { Do you have children? } \\
\text { Yes } \\
\text { No }\end{array}$ & $\begin{array}{l}155 \\
102\end{array}$ & $\begin{array}{l}60.3 \\
39.7\end{array}$ \\
\hline $\begin{array}{l}\text { Place of work } \\
\text { Intensive Care } \\
\text { Emergency Room } \\
\text { Administration } \\
\text { Ward-Outpatient clinic } \\
\end{array}$ & $\begin{array}{l}57 \\
56 \\
62 \\
82 \\
\end{array}$ & $\begin{array}{l}22.2 \\
21.8 \\
24.1 \\
31.9\end{array}$ \\
\hline \begin{tabular}{|l|} 
Occupational groups \\
Nurse \\
Doctor \\
Other \\
\end{tabular} & $\begin{array}{c}95 \\
52 \\
110 \\
\end{array}$ & $\begin{array}{l}37.0 \\
20.2 \\
42.8 \\
\end{array}$ \\
\hline $\begin{array}{l}\text { Marital status } \\
\text { Single } \\
\text { Married } \\
\end{array}$ & $\begin{array}{c}87 \\
170 \\
\end{array}$ & $\begin{array}{l}33.9 \\
66.1 \\
\end{array}$ \\
\hline $\begin{array}{l}\text { Smoking } \\
\text { Smoker } \\
\text { Non-smoker } \\
\end{array}$ & $\begin{array}{c}84 \\
173 \\
\end{array}$ & $\begin{array}{r}32.7 \\
67.3 \\
\end{array}$ \\
\hline $\begin{array}{l}\text { Do you drink alcohol? } \\
\text { Yes } \\
\text { No } \\
\end{array}$ & $\begin{array}{c}15 \\
242\end{array}$ & $\begin{array}{r}5.8 \\
94.2 \\
\end{array}$ \\
\hline $\begin{array}{l}\text { Do you have any psychiatric disorders? } \\
\text { Yes } \\
\text { No }\end{array}$ & $\begin{array}{c}5 \\
252 \\
\end{array}$ & $\begin{array}{c}1.9 \\
98.1\end{array}$ \\
\hline $\begin{array}{l}\text { Do you have any previous psychiatric } \\
\text { disorders? } \\
\text { Yes } \\
\text { No }\end{array}$ & $\begin{array}{c}6 \\
251\end{array}$ & $\begin{array}{c}2.3 \\
97.7\end{array}$ \\
\hline $\begin{array}{l}\text { Do you have any chronic diseases? } \\
\text { Yes } \\
\text { No }\end{array}$ & $\begin{array}{c}42 \\
215\end{array}$ & $\begin{array}{l}16.3 \\
83.7\end{array}$ \\
\hline $\begin{array}{l}\text { Have you stayed in a separate place } \\
\text { during the pandemic? } \\
\text { Yes } \\
\text { No }\end{array}$ & $\begin{array}{c}17 \\
240\end{array}$ & $\begin{array}{c}6.6 \\
93.4\end{array}$ \\
\hline $\begin{array}{l}\text { Are there adequate measures in the } \\
\text { hospital? } \\
\text { Yes } \\
\text { Partially } \\
\text { No }\end{array}$ & $\begin{array}{c}68 \\
117 \\
72\end{array}$ & $\begin{array}{l}26.5 \\
45.5 \\
28.0\end{array}$ \\
\hline $\begin{array}{l}\text { Have you considered resigning during } \\
\text { the pandemic? } \\
\text { Yes } \\
\text { No }\end{array}$ & $\begin{array}{c}18 \\
239\end{array}$ & $\begin{array}{c}7.0 \\
93.0\end{array}$ \\
\hline Total & 257 & 100.0 \\
\hline
\end{tabular}




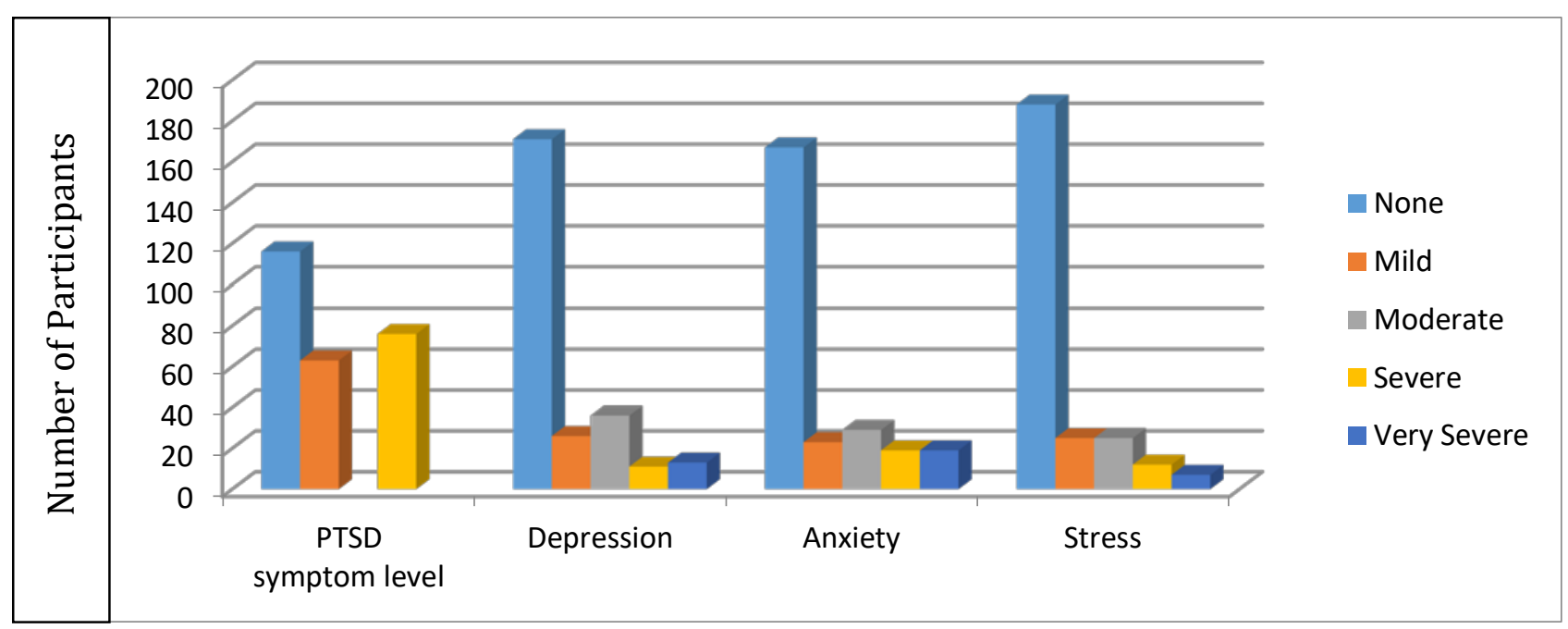

PTSD, Post-Traumatic Stress Disorder; DASS-42, Depression, Anxiety, sstress; TIES : , Turkish Impact of Events Scale

Figure 1: Comparison of DASS-42 and TIES

According to TIES, there was no significant relationship between the age groups and PTSD symptom level $(\mathrm{p}=0.198)$. The proportion of those without PTSD symptom level was $38(33.9 \%)$ in women and $78(53.8 \%)$ in men; the proportion of those with severe PTSD symptom level was $44(39.3 \%)$ in women and $34(23.4 \%)$ in men, and this was statistically significant $(\mathrm{p}=0.004)$. The proportion of those with severe PTSD symptom level was 64(32.8\%) in university graduates, whereas it was $14(22.6 \%)$ in graduates of high school and below, which was not statistically significant $(\mathrm{p}=0.245)$. Approximately $8(14 \%)$ of the intensive care staff, $17(27.4 \%)$ of the administrative staff, 25(30.4\%) of the ward and outpatient clinic staff had no PTSD symptom level, whereas this rate was $28(50 \%)$ in the emergency room staff, which was statistically significant $(p=0.001)$. Considering the occupational groups of the respondents, $34(35.8 \%)$ of nurses, $25(48.1 \%)$ of physicians, and $57(51.8 \%)$ of other healthcare workers did not have PTSD belirti düzeyi, and this was statistically significant $(\mathrm{p}=0.028)$. In addition, 31(35.6\%) of single individuals did not have PTSD symptom level, and this proportion was $85(50.0 \%)$ in the married individuals. The proportion of those with severe PTSD symptom level was $28(32.2 \%)$ in single individuals and $50(29.4 \%)$ in the married individuals, which was not statistically significant $(p=0.051)$. Severe PTSD symptom level was more common in non-smokers than in smokers (61(35.3\%), 17(20.2\%), respectively), which was statistically significant $(\mathrm{p}=0.043)$. There was no PTSD symptom level in $40(58.8 \%)$ of those who said that the measures taken in the hospital were adequate and in 29(40.2\%) of those who said adequate measures were not being taken. However, $14(20.6 \%)$ of those who said the measures taken were adequate had severe PTSD symptom level, whereas this proportion was $24(33.9 \%)$ in those who said adequate measures were not being taken, and this was statistically significant $(p=0.026)$ (Table II). 
Table II: Severity categories of PTSD symptom level.

\begin{tabular}{|c|c|c|c|c|}
\hline & $\begin{array}{c}\text { PTSD } \\
\text { symptom level none }\end{array}$ & $\begin{array}{l}\text { PTSD symptom level } \\
\text { mild }\end{array}$ & $\begin{array}{c}\text { PTSD symptom level } \\
\text { severe }\end{array}$ & $\begin{array}{c}P \\
\text { value }\end{array}$ \\
\hline $\begin{array}{l}\text { Age groups } \\
29 \text { y and under } \\
30-39 \text { y } \\
40 y \text { and older }\end{array}$ & $\begin{array}{l}34,4 \\
46,5 \\
51,1 \\
\end{array}$ & $\begin{array}{l}34,4 \\
21,8 \\
20,7 \\
\end{array}$ & $\begin{array}{l}31,2 \\
31,7 \\
28,3\end{array}$ & 0.198 \\
\hline $\begin{array}{l}\text { Gender } \\
\text { Male } \\
\text { Female } \\
\end{array}$ & $\begin{array}{l}53,8 \\
33,9 \\
\end{array}$ & $\begin{array}{l}22,8 \\
26,8 \\
\end{array}$ & $\begin{array}{l}23,4 \\
39,3 \\
\end{array}$ & 0.004 \\
\hline $\begin{array}{l}\text { Education } \\
\text { High school and below } \\
\text { University }\end{array}$ & $\begin{array}{l}53,2 \\
42,6 \\
\end{array}$ & $\begin{array}{l}24,2 \\
24,6 \\
\end{array}$ & $\begin{array}{l}22.6 \\
32.8\end{array}$ & 0.245 \\
\hline $\begin{array}{l}\text { Do you have children? } \\
\text { Yes } \\
\text { No } \\
\end{array}$ & $\begin{array}{l}50,3 \\
37,2\end{array}$ & $\begin{array}{l}20,0 \\
31,4\end{array}$ & $\begin{array}{l}29,7 \\
31,4\end{array}$ & 0,060 \\
\hline $\begin{array}{l}\text { Place of work } \\
\text { Intensive care } \\
\text { Emergency room } \\
\text { Administration } \\
\text { Ward-Outpatient clinic }\end{array}$ & $\begin{array}{l}49,1 \\
30,4 \\
45,2 \\
52,4\end{array}$ & $\begin{array}{l}36,8 \\
19,6 \\
27,4 \\
17,1\end{array}$ & $\begin{array}{l}14,0 \\
50.0 \\
27,4 \\
30,4\end{array}$ & 0.001 \\
\hline $\begin{array}{l}\text { Occupational groups } \\
\text { Nurse } \\
\text { Doctor } \\
\text { Other }\end{array}$ & $\begin{array}{l}35,8 \\
48,1 \\
51,8 \\
\end{array}$ & $\begin{array}{l}33,7 \\
13,5 \\
21,8 \\
\end{array}$ & $\begin{array}{l}30,5 \\
38,5 \\
26,4\end{array}$ & 0.028 \\
\hline $\begin{array}{l}\text { Marital status } \\
\text { Single } \\
\text { Married }\end{array}$ & $\begin{array}{l}35,6 \\
50,0\end{array}$ & $\begin{array}{l}32,2 \\
20,6\end{array}$ & $\begin{array}{l}32,2 \\
29,4\end{array}$ & 0.051 \\
\hline $\begin{array}{l}\text { Smoking } \\
\text { Smoker } \\
\text { Non-smoker }\end{array}$ & $\begin{array}{l}53,6 \\
41,0 \\
\end{array}$ & $\begin{array}{l}26,2 \\
23,7 \\
\end{array}$ & $\begin{array}{l}20,2 \\
35,3 \\
\end{array}$ & 0.043 \\
\hline $\begin{array}{l}\text { Do you drink alcohol? } \\
\text { Yes } \\
\text { No }\end{array}$ & $\begin{array}{l}40,0 \\
45,5\end{array}$ & $\begin{array}{l}33,3 \\
24,0\end{array}$ & $\begin{array}{l}26,7 \\
30,6\end{array}$ & 0.731 \\
\hline $\begin{array}{l}\text { Do you have any psychiatric disorders? } \\
\text { Yes } \\
\text { No }\end{array}$ & $\begin{array}{l}40,0 \\
45,2 \\
\end{array}$ & $\begin{array}{l}20,0 \\
24,6 \\
\end{array}$ & $\begin{array}{l}40,0 \\
30,2 \\
\end{array}$ & 0.896 \\
\hline $\begin{array}{l}\text { Do you have any previous psychiatric disorders? } \\
\text { Yes } \\
\text { No }\end{array}$ & $\begin{array}{l}16,7 \\
45,8\end{array}$ & $\begin{array}{l}16,7 \\
24,7\end{array}$ & $\begin{array}{l}66,6 \\
29,5\end{array}$ & 0.163 \\
\hline $\begin{array}{l}\text { Do you have any chronic diseases? } \\
\text { Yes } \\
\text { No } \\
\end{array}$ & $\begin{array}{l}52,4 \\
43,7 \\
\end{array}$ & $\begin{array}{l}16,6 \\
26,0 \\
\end{array}$ & $\begin{array}{l}31,0 \\
30,2 \\
\end{array}$ & 0.396 \\
\hline $\begin{array}{l}\text { Have you stayed in a separate place during the } \\
\text { pandemic? } \\
\text { Yes } \\
\text { No }\end{array}$ & $\begin{array}{l}29,4 \\
46,3 \\
\end{array}$ & $\begin{array}{l}29,4 \\
24,1 \\
\end{array}$ & $\begin{array}{l}41,2 \\
29,6 \\
\end{array}$ & 0.391 \\
\hline $\begin{array}{l}\text { Are there adequate measures in the hospital? } \\
\text { Yes } \\
\text { Partially } \\
\text { No }\end{array}$ & $\begin{array}{l}58,8 \\
40,2\end{array}$ & $\begin{array}{l}20,6 \\
25,9 \\
\end{array}$ & $\begin{array}{l}20,6 \\
33,9\end{array}$ & 0.026 \\
\hline $\begin{array}{l}\text { Have you considered resigning during the pandemic? } \\
\text { Yes } \\
\text { No }\end{array}$ & $\begin{array}{l}27,8 \\
46,4\end{array}$ & $\begin{array}{l}22,2 \\
24,7\end{array}$ & $\begin{array}{l}50.0 \\
28,9\end{array}$ & 0.150 \\
\hline
\end{tabular}

PTSD, Post-Traumatic Stress Disorder 
According to DASS, there was no statistically significant difference between age groups and depression $(\mathrm{p}=0.457)$. There was no depression in $111(76.6 \%)$, moderate depression in $16(11 \%)$, and severe depression in $3(2.1 \%)$ of men, whereas $60(53.6 \%)$ of women had no depression, 20(17.9\%) had moderate, and $10(8.9 \%)$ had severe depression, which was statistically significant $(\mathrm{p}=0.001)$. Considering the place of work, depression was most common in the emergency room, and least common in the intensive care unit, and this was statistically significant $\quad(p=0.043)$. When analyzed by profession, depression was most common in nurses, and least common in healthcare workers other than nurses and doctors, but there was no statistically significant difference $(p=0.661)$ (Table III).

Table III: Severity categories of depression.

\begin{tabular}{|c|c|c|c|c|c|c|}
\hline & \multicolumn{5}{|c|}{ DASS-42, Depression } & \multirow[b]{2}{*}{$P$ value } \\
\hline & None & Mild & Moderate & Severe & Very severe & \\
\hline \multicolumn{7}{|l|}{ Age groups } \\
\hline $29 \mathrm{y}$ and under & 68,8 & 6,3 & 14,1 & 7,8 & 3,1 & \multirow{3}{*}{0.457} \\
\hline $30-39 y$ & 67,3 & 7,9 & 13,9 & 4,0 & 6,9 & \\
\hline $40 \mathrm{y}$ and older & 64,1 & 15,2 & 14,1 & 2,2 & 4,3 & \\
\hline \multicolumn{7}{|l|}{ Gender } \\
\hline Male & 76,6 & 8,3 & 11,0 & 2,1 & 2,1 & \multirow{2}{*}{0.001} \\
\hline Female & 53,6 & 12,5 & 17,9 & 7,1 & 8,9 & \\
\hline \multicolumn{7}{|l|}{ Education } \\
\hline High school and below & 67,7 & 9,7 & 12,9 & 3,2 & 6,5 & \multirow{2}{*}{0,960} \\
\hline University & 66,2 & 10,3 & 12,4 & 4,6 & 4,6 & \\
\hline \multicolumn{7}{|l|}{ Do you have children? } \\
\hline Yes & 65,8 & 12,3 & 12,9 & 3,9 & 5,2 & \multirow{2}{*}{0.680} \\
\hline No & 67,6 & 6,9 & 15,7 & 4,9 & 4,9 & \\
\hline \multicolumn{7}{|l|}{ Place of work } \\
\hline Intensive care & 71,9 & 7,0 & 12,3 & 3,5 & 5,3 & \multirow{4}{*}{0.043} \\
\hline Emergency room & 53,6 & 12,5 & 10,7 & 10,7 & 12,5 & \\
\hline Administration & 74,2 & 8,1 & 12,9 & 3,2 & 1,6 & \\
\hline Ward-Outpatient clinic & 65,9 & 12,2 & 18,3 & 1,2 & 2,4 & \\
\hline \multicolumn{7}{|l|}{ Occupational groups } \\
\hline Nurse & 61,1 & 11,6 & 13,7 & 6,3 & 7,4 & \multirow{3}{*}{0.661} \\
\hline Doctor & 65,4 & 9,6 & 15,4 & 5,8 & 3,8 & \\
\hline Other & 71,8 & 9,1 & 13,6 & 1,8 & 3,6 & \\
\hline \multicolumn{7}{|l|}{ Marital status } \\
\hline Single & 62,1 & 10,3 & 14,0 & 5,7 & 6,9 & \multirow{2}{*}{0.731} \\
\hline Married & 68,8 & 10,0 & 13,5 & 3,5 & 4,1 & \\
\hline \multicolumn{7}{|l|}{ Smoking } \\
\hline Smoker & 70,2 & 10,7 & 13,1 & 3,6 & 2,4 & \multirow{2}{*}{0,637} \\
\hline Non-smoker & 64,7 & 9,8 & 14,5 & 4,6 & 6,4 & \\
\hline \multicolumn{7}{|l|}{ Do you drink alcohol? } \\
\hline Yes & 80,0 & 6,7 & 13,3 & 0,0 & 0,0 & 0.476 \\
\hline
\end{tabular}




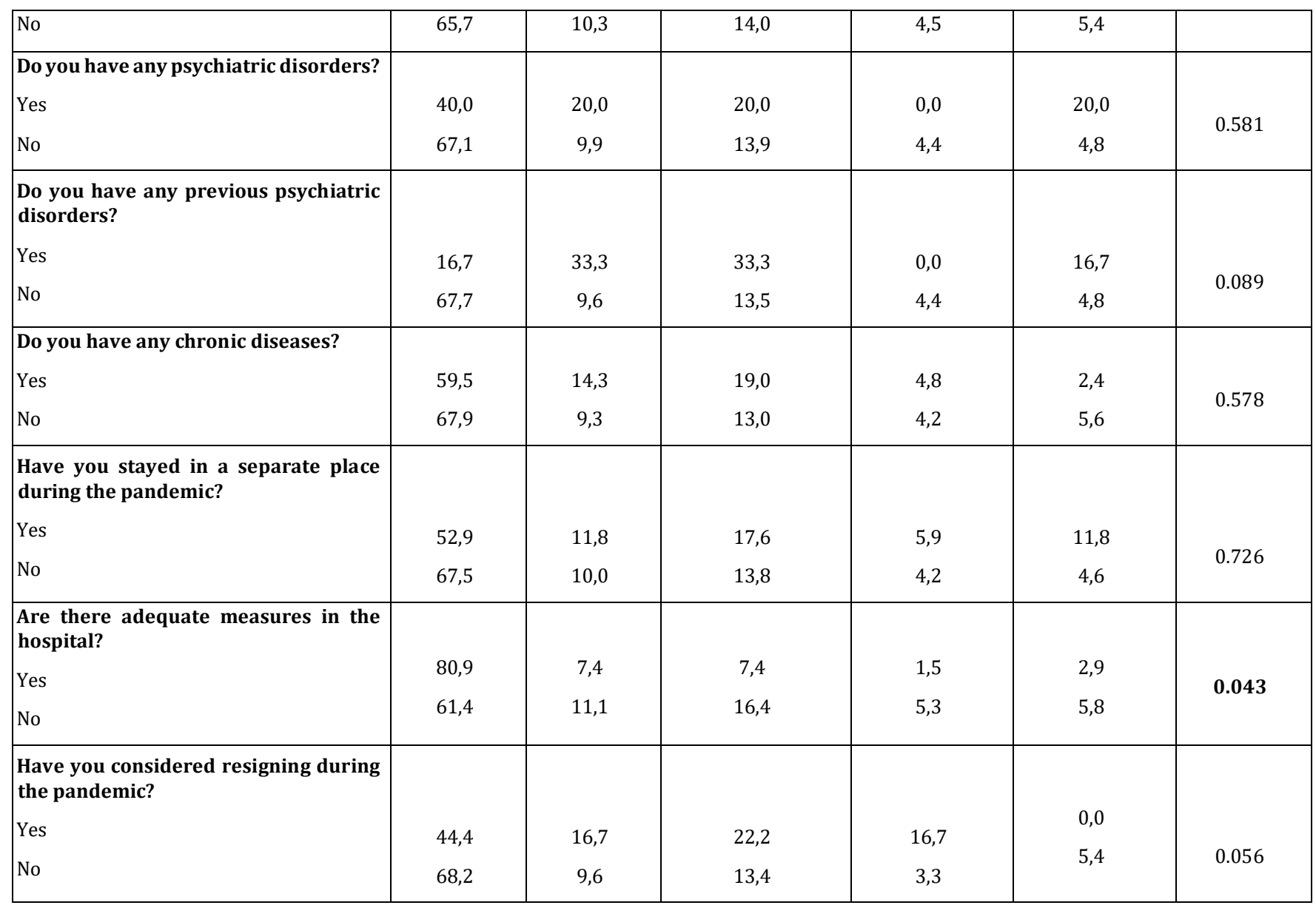

DASS-42, Depression Anxiety Stress Scales

Anxiety was not present in 105(72.4\%), moderate in $14(9.7 \% 9$, and severe in $7(4.8 \%)$ of men; whereas it was absent in 62(55.4\%) of women, moderate in $15(13.4 \%)$, and severe in $12(10.7 \%)$ of them, but this was not statistically significant $(\mathrm{p}=0.065)$. Considering the place of work, anxiety was most common in the emergency room 27(48.2\%) and least common in the intensive care unit $16(28.1 \%)$, which was statistically significant $(\mathrm{p}=0.004)$. When analyzed by profession, anxiety was most common in nurses 39(41.1\%) and other healthcare workers had less anxiety, but there was no statistically significant difference $(\mathrm{p}=0.775)$ (Table IV).

Stress was not present in $118(81.4 \%)$ and moderate in $9(6.2 \%)$ of men; whereas $70(62.5 \%)$ of women were not stressed,
$16(14.3 \%)$ were moderately stressed, and $6.3 \%$ were severely stressed, and this was statistically significant $(\mathrm{p}=0.001)$. Considering the place of work, stress was most common in the emergency room 21(37.5\%) and least common in the intensive care unit $12(21.1 \%)$. In addition, $6(10.7 \%)$ of the emergency room workers had severe stress, and this was statistically significant $(\mathrm{p}=0.039)$. When analyzed by profession, stress was most common among nurses 29(30.5\%) and least common in healthcare workers other than nurses and doctors $26(23.6 \%)$, but there was no statistically significant difference $(\mathrm{p}=0.432)$. 
Yalçın G., Sayınbatur B., Karay E., Karakaş M.

Table IV: Severity categories of anxiety.

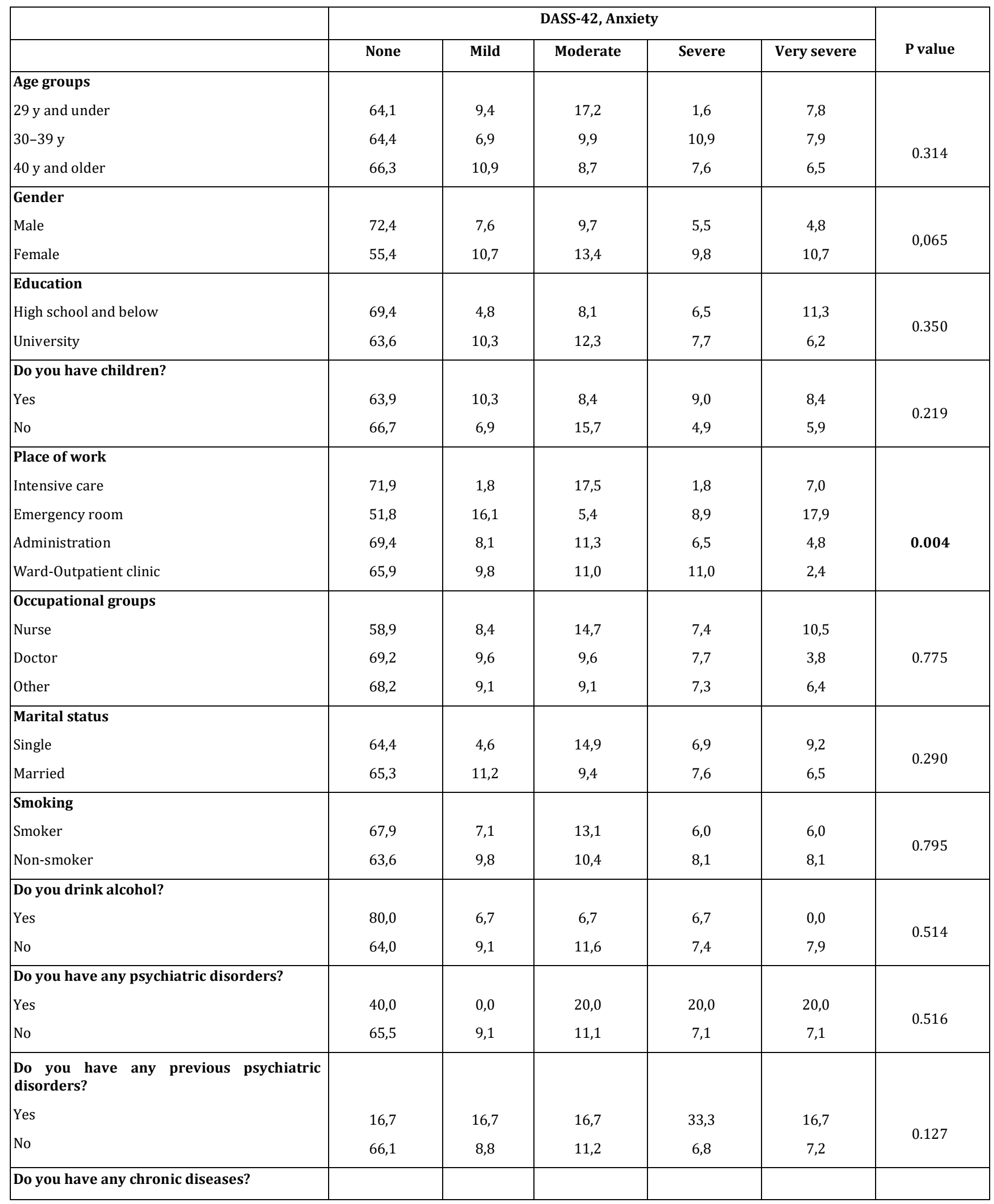




\begin{tabular}{|c|c|c|c|c|c|c|}
\hline $\begin{array}{l}\text { Yes } \\
\text { No }\end{array}$ & $\begin{array}{l}66,7 \\
64,6\end{array}$ & $\begin{array}{l}9,5 \\
8,8\end{array}$ & $\begin{array}{l}11,9 \\
11,2\end{array}$ & $\begin{array}{l}9,5 \\
7,0\end{array}$ & $\begin{array}{l}2,4 \\
8,4\end{array}$ & 0.635 \\
\hline \multicolumn{7}{|c|}{$\begin{array}{l}\text { Have you stayed in a separate place during } \\
\text { the pandemic? }\end{array}$} \\
\hline Yes & 52,9 & 11,8 & 23,5 & 0,0 & 11,8 & \multirow[t]{2}{*}{0.243} \\
\hline No & 65,8 & 8,8 & 10,4 & 7,9 & 7,1 & \\
\hline \multicolumn{7}{|c|}{$\begin{array}{l}\text { Are there adequate measures in the } \\
\text { hospital? }\end{array}$} \\
\hline Yes & 77,9 & 5,9 & 8,8 & 4,4 & 2,9 & \multirow{2}{*}{0,114} \\
\hline No & 60,3 & 10,1 & 12,2 & 8,5 & 9,0 & \\
\hline \multicolumn{7}{|c|}{$\begin{array}{l}\text { Have you considered resigning during the } \\
\text { pandemic? }\end{array}$} \\
\hline
\end{tabular}

DASS-42, Depression Anxiety Stress Scales

The proportion of those with stress in individuals who had no previous psychiatric disease was $65(25.9 \%)$, but only $2(33.3 \%)$ of those who previously had a psychiatric condition had no stress according to the scale at the time of the study, which was statistically significant $(\mathrm{p}=0.030)$. The proportion those having stress in individuals who considered resigning during the pandemic was $9(50.0 \%)$, but it was $60(25.1 \%)$ in those who did not consider resigning, and this difference was statistically significant $(\mathrm{p}=0.023)$. Approximately $9(13.2 \%)$ of respondents who said that adequate measures had been taken in the hospital had stress, whereas $23(31.7 \%)$ of those who said hospital measures were inadequate had stress, and this was statistically significant $(p=0.002)$ (Table V).

Table V: Severity categories of stress.

\begin{tabular}{|c|c|c|c|c|c|c|}
\hline & \multicolumn{5}{|c|}{ DASS-42, Stress } & \multirow[b]{2}{*}{ P value } \\
\hline & None & Mild & Moderate & Severe & Very severe & \\
\hline \multicolumn{7}{|l|}{ Age groups } \\
\hline $29 \mathrm{y}$ and under & 73,4 & 10,9 & 10,9 & 3,1 & 1,6 & \multirow{3}{*}{0.881} \\
\hline $30-39 y$ & 69,3 & 9,9 & 11,9 & 5,0 & 4,0 & \\
\hline $40 \mathrm{y}$ and older & 77,2 & 8,7 & 6,5 & 5,4 & 2,2 & \\
\hline \multicolumn{7}{|l|}{ Gender } \\
\hline Male & 81,4 & 9,0 & 6,2 & 3,4 & 0,0 & \multirow{2}{*}{0.001} \\
\hline Female & 62,5 & 10,7 & 14,3 & 6,3 & 6,3 & \\
\hline \multicolumn{7}{|l|}{ Education } \\
\hline High school and below & 79,0 & 6,5 & 6,5 & 6,5 & 1,6 & \multirow{2}{*}{0.511} \\
\hline University & 71,3 & 10,8 & 10,8 & 4,1 & 3,1 & \\
\hline \multicolumn{7}{|l|}{ Do you have children? } \\
\hline Yes & 75,5 & 8,4 & 8,4 & 4,5 & 3,2 & \multirow{2}{*}{0.716} \\
\hline No & 69,6 & 11,8 & 11,8 & 4,9 & 2,0 & \\
\hline Place of work & & & & & & \\
\hline
\end{tabular}


Yalçın G., Sayınbatur B., Karay E., Karakaş M.

\begin{tabular}{|c|c|c|c|c|c|c|}
\hline Intensive care & 78,9 & 5,3 & 10,5 & 3,5 & 1,8 & \\
\hline Emergency room & 62,5 & 7,1 & 14,3 & 5,4 & 10,7 & 0.039 \\
\hline Administration & 75,8 & 12,9 & 6,5 & 4,8 & 0,0 & \\
\hline Ward-Outpatient clinic & 74,4 & 12,2 & 8,5 & 4,9 & 0,0 & \\
\hline \multicolumn{7}{|l|}{ Occupational groups } \\
\hline Nurse & 69,5 & 7,4 & 13,7 & 5,3 & 4,2 & \multirow{3}{*}{0.432} \\
\hline Doctor & 73,1 & 11,5 & 9,6 & 1,9 & 3,8 & \\
\hline Other & 76,4 & 10,9 & 6,4 & 5,5 & 0,9 & \\
\hline \multicolumn{7}{|l|}{ Marital status } \\
\hline Single & 67,8 & 11,5 & 11,5 & 5,7 & 3,4 & \multirow{2}{*}{0.754} \\
\hline Married & 75,9 & 8,8 & 8,8 & 4,1 & 2,4 & \\
\hline \multicolumn{7}{|l|}{ Smoking } \\
\hline Smoker & 78,6 & 7,1 & 9,5 & 3,6 & 1,2 & \multirow[t]{2}{*}{0.560} \\
\hline Non-smoker & 70,5 & 11,0 & 9,8 & 5,2 & 3,5 & \\
\hline \multicolumn{7}{|l|}{ Do you drink alcohol? } \\
\hline Yes & 80,0 & 6,7 & 13,3 & 0,0 & 0,0 & \multirow{2}{*}{0.601} \\
\hline No & 72,7 & 9,9 & 9,5 & 5,0 & 2,9 & \\
\hline \multicolumn{7}{|c|}{ Do you have any psychiatric disorders? } \\
\hline Yes & 60,0 & 0,0 & 20,0 & 0,0 & 20,0 & \multirow{2}{*}{0.357} \\
\hline No & 73,4 & 9,9 & 9,5 & 4,8 & 2,4 & \\
\hline \multicolumn{7}{|c|}{$\begin{array}{l}\text { Do you have any previous psychiatric } \\
\text { disorders? }\end{array}$} \\
\hline Yes & 33,3 & 0 & 50,0 & 0,0 & 16,7 & \multirow{2}{*}{0.030} \\
\hline No & 74,1 & 10,0 & 8,8 & 4,8 & 2,4 & \\
\hline \multicolumn{7}{|c|}{ Do you have any chronic diseases? } \\
\hline Yes & 71,4 & 7,1 & 14,3 & 7,1 & 0,0 & \multirow{2}{*}{0.350} \\
\hline No & 73,5 & 10,2 & 8,8 & 4,2 & 3,3 & \\
\hline \multicolumn{7}{|c|}{$\begin{array}{l}\text { Have you stayed in a separate place } \\
\text { during the pandemic? }\end{array}$} \\
\hline Yes & 76,5 & 5,9 & 5,9 & 0,0 & 11,8 & \multirow{2}{*}{0.241} \\
\hline No & 72,9 & 10,0 & 10,0 & 5,0 & 2,1 & \\
\hline \multicolumn{7}{|c|}{$\begin{array}{l}\text { Are there adequate measures in the } \\
\text { hospital? }\end{array}$} \\
\hline Yes & 86,8 & 5,9 & 1,5 & 5,9 & 0,0 & \multirow[t]{2}{*}{0.002} \\
\hline No & 68,3 & 11,1 & 12,7 & 4,2 & 3,7 & \\
\hline \multicolumn{7}{|c|}{$\begin{array}{l}\text { Have you considered resigning during } \\
\text { the pandemic? }\end{array}$} \\
\hline Yes & 50,0 & 5,6 & 33,3 & 1,1 & 0,0 & \multirow{2}{*}{0.023} \\
\hline No & 74,9 & 10,0 & 7,9 & 4,2 & 4,2 & \\
\hline
\end{tabular}

DASS-42, Depression Anxiety Stress Scales. 
According to the results of the multivariate logistic regression analysis; PTSD symptom level, DASS-depression, DASS-anxiety, and DASS-stress were significantly higher in women than in men [(2.02; \%95Cl, 1.09-3.73; $\mathrm{P}=0.026)$, $((2.97 ; \quad \% 95 \mathrm{Cl}, \quad 1.61-5.47 ; \quad \mathrm{P}=0.001), \quad(2.20$; \%95Cl, 1.23-3.97; $\mathrm{P}=0.008),(2.57 ; \% 95 \mathrm{Cl}, 1.36-$ 4.86; $\mathrm{P}=0.004)$, respectively]. PTSD symptom level rates of emergency room workers were significantly higher than those of the workers in other departments $(2.47$; $\% 95 \mathrm{Cl}, 1.25-4.91$; $\mathrm{P}=0.010$ ). According to those who stated that the infection measures taken in the hospital were insufficient, the rates of depression, anxiety and stress was significantly higher than those who stated that they were sufficient [(3.93; 95\%Cl, 1.51-7.18; $\mathrm{P}=0.003),(2.54 ; 95 \%$ $\mathrm{Cl}, 1.23-5.23 ; \mathrm{P}=0.011),(3.47 ; 95 \% \mathrm{Cl}, 1.47-8.18$; $\mathrm{P}=0.004)$, respectively]. The rates of depression, anxiety, and stress was significantly higher in employees who previously had psychiatric disease than those who did not have disease before [(14.86; 95\% Cl, 1.37-160.7; $\mathrm{P}=0.026),(12.40 ; 95 \% \mathrm{Cl}, 1.20-128.3 ; \mathrm{P}=0.035)$, (6.90; \% $95 \mathrm{Cl}, 1.01-47.36, \quad \mathrm{P}=0.049$ ), respectively] (Table VI).

Table VI: Sociodemographic Risk Factors for Mental Health Results Identified by Multivariate Logistic Regression Analysis

\begin{tabular}{|c|c|c|c|c|c|c|c|c|}
\hline & \multicolumn{2}{|c|}{ PTSD symptom level } & \multicolumn{2}{|c|}{ DASS Depression } & \multicolumn{2}{|c|}{ DASS Anxiety } & \multicolumn{2}{|c|}{ DASS Stress } \\
\hline & $\begin{array}{c}\text { Adjusted Cl } \\
\text { (\%95) }\end{array}$ & $\begin{array}{c}P \\
\text { value }\end{array}$ & \begin{tabular}{|l} 
Adjusted \\
$(\% 95)$
\end{tabular} & $\begin{array}{c}P \\
\text { value }\end{array}$ & $\begin{array}{c}\text { Adjusted Cl } \\
\text { (\%95) }\end{array}$ & $\begin{array}{c}\text { P } \\
\text { value }\end{array}$ & $\begin{array}{c}\text { Adjusted Cl } \\
(\% 95)\end{array}$ & $\begin{array}{c}P \\
\text { value }\end{array}$ \\
\hline $\begin{array}{l}\text { Gender } \\
\text { Male } \\
\text { Female }\end{array}$ & $\begin{array}{c}1 \\
2.02(1.09-3.73)\end{array}$ & 0.026 & $\begin{array}{c}1 \\
2,97(1,61-5,47)\end{array}$ & $<0,001$ & $\begin{array}{c}1 \\
2.21(1.23-3.97)\end{array}$ & 0.008 & $\begin{array}{c}1 \\
2.57(1.36- \\
4.86)\end{array}$ & 0.004 \\
\hline $\begin{array}{l}\text { Education } \\
\text { High school and } \\
\text { below } \\
\text { University }\end{array}$ & $\begin{array}{c}1 \\
0.72(0.32-1.59)\end{array}$ & 0.412 & $\begin{array}{c}1 \\
1,40(0.65-3.01)\end{array}$ & 0.384 & $\begin{array}{c}1 \\
0.86(0.41-1.79)\end{array}$ & 0.687 & $\begin{array}{c}1 \\
0.75(0.33- \\
1.70)\end{array}$ & 0.489 \\
\hline $\begin{array}{l}\text { Marital status } \\
\text { Married } \\
\text { Single }\end{array}$ & $\begin{array}{c}1 \\
0.83(0.30-2.28)\end{array}$ & 0.715 & $\begin{array}{c}1 \\
2.51(0.83-7.62)\end{array}$ & 0.105 & $\begin{array}{c}1 \\
1.10(0.41-2.95)\end{array}$ & 0.845 & $\begin{array}{c}1 \\
1.35(0.47- \\
3.82)\end{array}$ & 0.577 \\
\hline $\begin{array}{l}\text { Place of work } \\
\text { Intensive care } \\
\text { Emergency room } \\
\text { Administration } \\
\text { Ward-Outpatient } \\
\text { clinic }\end{array}$ & $\begin{array}{c}1 \\
2.47(1.25-4.91)\end{array}$ & 0.010 & $\begin{array}{c}1 \\
0.70(0.35-1.38)\end{array}$ & 0.295 & $\begin{array}{c}1 \\
0.60(0.31-1.17)\end{array}$ & 0.131 & $\begin{array}{c}1 \\
0.66(0.32- \\
1.36)\end{array}$ & 0.256 \\
\hline $\begin{array}{l}\text { Occupational } \\
\text { groups } \\
\text { Other } \\
\text { Doctor } \\
\text { Nurse }\end{array}$ & $\begin{array}{c}1 \\
0.61(0.28-1.32) \\
1.11(0.48-2.55)\end{array}$ & $\begin{array}{l}0.208 \\
0.805\end{array}$ & $\begin{array}{c}1 \\
1.10(0.53-2.32) \\
1.290 .55-3.06)\end{array}$ & $\begin{array}{l}0.797 \\
0.552\end{array}$ & $\begin{array}{c}1 \\
0.99(0.49-2.01) \\
0.74(0.32-1.71)\end{array}$ & $\begin{array}{l}0.977 \\
0.482\end{array}$ & $\begin{array}{c}1 \\
0.62(0.29- \\
1.34) \\
0.80(0.33- \\
1.96)\end{array}$ & $\begin{array}{l}0.222 \\
0.630\end{array}$ \\
\hline
\end{tabular}




\begin{tabular}{|c|c|c|c|c|c|c|c|c|}
\hline $\begin{array}{lll}\begin{array}{l}\text { Do you } \\
\text { children? }\end{array} & \\
\text { No } & & \\
\text { Yes } & & \\
\end{array}$ & $\begin{array}{c}1 \\
0.96(0.35-2.60)\end{array}$ & 0.929 & $\begin{array}{c}1 \\
2.25(0.75-6.80)\end{array}$ & 0.149 & $\begin{array}{c}1 \\
1.37(0.52-3.61)\end{array}$ & 0.519 & $\begin{array}{c}1 \\
0.92(0.32- \\
2.59)\end{array}$ & 0.867 \\
\hline $\begin{array}{l}\text { Smoking } \\
\text { Smoker } \\
\text { Non-smoker }\end{array}$ & $\begin{array}{c}1 \\
2.33(1.17-4.63)\end{array}$ & 0.016 & $\begin{array}{c}1 \\
0.72(0.38-1.36)\end{array}$ & 0.311 & $\begin{array}{c}1 \\
0.76(0.41-1.40)\end{array}$ & 0.373 & $\begin{array}{c}1 \\
0.60(0.31- \\
1.20)\end{array}$ & 0.148 \\
\hline $\begin{array}{l}\text { Have you } \\
\text { considered } \\
\text { resigning during } \\
\text { the pandemic? } \\
\text { No } \\
\text { Yes }\end{array}$ & $\begin{array}{c}1 \\
1.40(0.47-4.11)\end{array}$ & 0.547 & $\begin{array}{c}1 \\
1.33(0.45-3.93)\end{array}$ & 0.606 & $\begin{array}{c}1 \\
0.55(0.18-1.67)\end{array}$ & 0.291 & $\begin{array}{c}1 \\
1.45(0.50- \\
4.19)\end{array}$ & 0.489 \\
\hline $\begin{array}{l}\text { Have you stayed } \\
\text { in a separate } \\
\text { place during the } \\
\text { pandemic? } \\
\text { No } \\
\text { Yes }\end{array}$ & $\begin{array}{c}1 \\
1.39(0.47-4.11)\end{array}$ & 0.595 & $\begin{array}{c}1 \\
1.67(0.52-5.32)\end{array}$ & 0.386 & $\begin{array}{c}1 \\
1.65(0.54-5.02)\end{array}$ & 0.380 & $\begin{array}{c}1 \\
0.54(0.14- \\
2.07)\end{array}$ & 0.369 \\
\hline $\begin{array}{l}\text { Do you have any } \\
\text { previous } \\
\text { psychiatric } \\
\text { disorders? } \\
\text { No } \\
\text { Yes }\end{array}$ & $\begin{array}{c}1 \\
5.56(0.83-37.43)\end{array}$ & 0.078 & $\begin{array}{c}1 \\
14.86(1.37- \\
160.7)\end{array}$ & 0.026 & $\begin{array}{c}1 \\
12.40(1.20- \\
128.3)\end{array}$ & 0.035 & $\begin{array}{c}1 \\
6.90(1.01- \\
47.36)\end{array}$ & 0.049 \\
\hline $\begin{array}{l}\text { Are there } \\
\text { adequate in the } \\
\text { measures in } \\
\text { hospital? } \\
\text { Yes } \\
\text { No }\end{array}$ & $\begin{array}{c}1 \\
2.07(0.98-4.36)\end{array}$ & 0.057 & $\begin{array}{c}1 \\
3.93(1.51-7.18)\end{array}$ & 0.003 & $\begin{array}{c}1 \\
2.54(1.23-5.23)\end{array}$ & 0.011 & $\begin{array}{c}1 \\
3.47(1.47- \\
8.18)\end{array}$ & 0.004 \\
\hline Age & $0.99(0.95-1.03)$ & 0,625 & $1.03(0.99-1.07)$ & 0.151 & $1.01(0.97-1.05)$ & 0.642 & $\begin{array}{c}1.01(0.97- \\
1.05)\end{array}$ & 0.794 \\
\hline
\end{tabular}

PTSD: post-traumatic stress disorder, DASS-42: Depression Anxiety Stress Scales, Cl: Confidence Interval

\section{DISCUSSION}

Adverse psychological consequences have affected the healthcare workers as well as the general population during the COVID-19 pandemic. Although the hospital where this study was conducted does not serve as a pandemic hospital, a special service was organized for the hospitalization of possible Covid-19 cases. In this study period, the results of 6 patients who were evaluated as possible Covid-19 were negative. In this study; employees were not evaluated as employees in Covid service and other services. Approximately $54.9 \%$ of the respondents showed signs of PTSD symptom level, $33.5 \%$ of depression, $35 \%$ of anxiety, and $26.8 \%$ of stress, and these rates are similar to those reported in previous studies ${ }^{16,17}$. Although the hospital where the study is conducted is not a pandemic hospital, 
these results show that those working in pandemic hospitals may have higher psychiatric complaints. Since the study was conducted at the beginning of the epidemic, we can predict that the results may be more advanced in the future. In the present study, the rates of PTSD symptom level, depression, anxiety, and stress were higher in women than in men. We can interpret it as it is because women have more responsibilities regarding social life and family outside of work. Our findings show that not all healthcare professionals are affected by the COVID-19 outbreak to the same extent. This rate was significant in the emergency room workers. Among the workers, the rate in nurses was found to be higher. This was consistent with the literature ${ }^{18}$. As first contact with Covid-19 patients occurs in the emergency room in our hospital, nurses have intensive contact with patients and are subject to the highest risk of infection due to long working hours. Emergency room staffs have been struggling to provide quality service, and they have been experiencing more difficulties in psychological terms than those working in other departments. In the present study, it was found that $6.6 \%$ of the respondents stayed in separate places and $7.0 \%$ considered resigning. This proportion is different from that reported in the literature ${ }^{19}$. We believe that the reason for the occurrence of few cases is because our hospital is a pediatric hospital and that $72 \%$ of the employees believed that the measures taken in the hospital were partially or completely adequate. Nonsmokers had higher PTSD symptoms than smokers. Although smoking is also evaluated as a method of coping with stress by smokers, data to support this was not evaluated in our study. Although the findings determined according to the scale evaluations made in patients with previous and current psychiatric diseases are statistically insignificant, the reason for this is the very low number of patients with psychiatric diseases. This group of employees should be very careful. Because as the stress burden increases in healthcare professionals such as nurses, suicide rates also increase ${ }^{20}$.

Although studies conducted during the COVID19 pandemic in China showed moderate and severe psychological symptoms in the general population, this was not the finding for the hospital workers in the present study ${ }^{21}$. This situation can be explained by the fact that the study is at an early stage, does not serve as a pandemic hospital, only serves as a children's hospital, and the Ministry of Health takes and takes measures rapidly. Although the psychological effect of COVID-19 was found to be more common in healthcare workers without medical training in the studies ${ }^{22}$, PTSD symptom level was less common in healthcare workers other than doctors and nurses. This is thought to be due to the fact that we had very little contact with the covid-19 patient in the first periods, as we serve as a children's hospital.

It can be estimated that health and social care professionals on the frontline would be at high risk, especially in terms of psychological disorders. In emergency cases, disorders that may occur in the long term such as burnout, depression, and post-traumatic stress disorder can be avoided by managing stress well and providing expert assistance. Frontline workers, including healthcare workers, should be particularly focused on with respect to this. Psychological therapies should not be ignored at any stage of the pandemic period.

This study is important in terms of contributing to the literature in terms of early evaluation and monitoring of the mental health status of healthcare workers in the early stages of future infectious disease outbreaks and also in terms of applying a more active, systematic and scientific psychological support treatment in long-term pandemic processes.

\section{LIMITATIONS}


There were some limitations in this study. The first was that this was a pediatric hospital; therefore, there were fewer cases. Second, the study was conducted within a short period of time. Third, as of the region where this study was conducted, people were accustomed to psychological stress load because their living conditions were difficult for various reasons. Fourth, the number of participants was limited. Lastly, the long-term results could not be evaluated.

\section{CONCLUSION}

In this study, it was determined that during the Covid-19 pandemic, psychological stress levels significantly increased in healthcare providers. To promote mental well-being in healthcare workers, adequate working conditions, especially for women, nurses, and frontline workers, necessary and adequate medical protective equipment, adequate resting periods as well as multidisciplinary programs such as psychological support should be provided and immediately put into practice. Providing scientific and regular information to healthcare workers during the management of the pandemic process prevents the psychological stress levels of the employees from increasing. In addition, psychological support is thought to be important in increasing the quality of medical services. Additional studies are recommended to investigate the long-term impact of the COVID-19 outbreak on the psychological state of healthcare workers.

Ethics Committee Approval: Ethical approval for the study was obtained from the Republic of Turkey Ministry of Health General Directorate of Health Services and Health Sciences University Diyarbakır Gazi Yaşargil Training and Research Hospital (472. 05/15/2020). Informed consent was obtained from all participants. Data were collected within 10 days (March 23-April 01, 2020).
Declaration of Conflicting Interests: The authors declare that they have no conflict of interest.

Financial Disclosure: No financial support was received.

\section{REFERENCES}

1. World Health Organization. Statement on the second meeting of the International Health Regulations (2005) Emergency Committee about the outbreak of novel coronavirus (2019-nCoV), 2020. Available from: https://wwwwhoint/newsroom/detail/30-01-2020-statement-on-thesecond-meeting-of-the-international-healthregulations-(2005)-emergency-committeeregarding-the-outbreak-of-novel-coronavirus(2019-ncov). Accessed on. 17th February 2020.

2. Erdoğan A, Hocaoğlu Ç. Psychiatric aspect of infectious diseases and pandemic: A review, Klinik Psikiyatri Dergisi. 2020; 23. DOI: 10.5505/kpd.2020.90277 2020, 23.

3. Enli TF, Koyuncu E, Özel Ş. A review of protective and risk factors affecting psychosocial health of healthcare workers in pandemics. Ankara Med J. 2020; 20: 488-504. DOI: 10.5505/amj.2020.02418.

4. Feng MC, Wu HC, Lin HT, et al. Exploring the stress, psychological distress, and stress-relief strategies of Taiwan nursing staffs facing the global outbreak of COVID-19. Hu Li Za Zhi. 2020; 3: 64-74. DOI: 10.6224 / JN.202006_67 (3) .09.

5. Walton M, Murray E, Christian MD. Mental health care for medical staff and affiliated healthcare workers during the COVID-19 pandemic. Eur Heart J Acute Cardiovasc Care. 2020: 2048872620922795. DOI: $10.1177 / 2048872620922795$.

6. Matsuishi K, Kawazoe A, Imai $H$, et al. Psychological impact of the pandemic (H1N1) 2009 on general hospital workers in Kobe. Psychiatry Clin Neurosci. 2012; 66: 353-60. DOI: 10.1111/j.14401819.2012.02336.x.

7. Bansal P, Bingemann TA, Greenhawt $M$, et al. Clinician wellness during the COVID-19 pandemic: extraordinary times and unusual challenges for the allergist/immunologist. Allergy Clin Immunol Pract. 2020; 6: 1781-90.e3. DOI: 10.1016/j.jaip.

2020.04.001. 
8. Sohrabi C, Alsafi Z, O'Neill N, et al. World Health Organization declares global emergency: A review of the 2019 novel coronavirus (COVID-19). Int J Surg. 2020; 76: 71-6. DOI: 10.1016 / j.ijsu.2020.02.034.

9. Bohlken J, Schömig F, Lemke MR, et al. COVID-19 pandemic: stress experience of healthcare workers a short current review. Psychiatr Prax. 2020; 47: 190-7. DOI: 10.1055 / a-1159-5551.

10. Chew NWS, Lee GKH, Tan BYQ, et al. A multinational, multicentre study on the psychological outcomes and associated physical symptoms amongst healthcare workers during COVID-19 Outbreak. Brain Behav Immun. 2020; 20: 30523-7. DOI: 10.1016/j.bbi.2020.04.049.

11. Etxebarria NO, Santamaria MD, Gorrochategui $\mathrm{MP}$, et al. Stress, anxiety, and depression levels in the initial stage of the COVID-19 outbreak in a population sample in the Northern Spain. Cad Saude Publica. 2020; 36: e00054020. DOI: 10.1590 / 0102311X00054020.

12. Weiss DS, Marmar CR. The impact of event scale - revised. In: Wilson JP, Keane TM, editors. Assessing psychological trauma and PTSD. New York: Guilford Press; 1997. pp. 399-411.

13. Çorapçıŏlu A, Yargıç İ, Geyran P, et al. Validity and reliability of Turkish version of "Impact of Event Scale-Revised" (IES-R). New Symposium Journal. 2006; 44: 14-22.

14. Lovibond PF, Lovibond SH. The structure of negative emotional states: Comparison of the depression anxiety stress scales (dass) with the beck depression and anxiety inventories. Behav. Res. Ther. 1995; 33: 335-43.

15. Bayram N, Bilgel N. The prevalence and sociodemographic correlations of depression, anxiety and stress among a group of university students. Soc
Psychiatry Psychiatr Epidemiol 2008; 43: 667-72. DOI:10.1007/s00127-008-0345-x.

16. Huang JZ, Han MF, Luo TD, et al. Mental health survey of medical staff in a tertiary infectious disease hospital for COVID-19. Zhonghua Lao Dong Wei Sheng Zhi Ye Bing Za Zhi. 2020; 3: 192-5. DOI: 10.3760/cma.j.cn121094-20200219-00063.

17. Chou R, Dana T, Buckley DI, et al. Epidemiology of and risk factors for Coronavirus infection in health care workers. Ann Intern Med. 2020; 5: M201632. DOI: 10.7326 / M20-1632.

18. Lai J, Ma S, Wang Y, et al. Factors associated with mental health outcomes among health care workers exposed to coronavirus disease 2019. JAMA Netw Open. 2020; 3: e20397. DOI: 10.1001/jamanetworkopen.2020.3976.

19. Shah K, Chaudhari G, Kamrai D, et al. How essential is to focus on physician's health and burnout in Coronavirus (COVID-19) pandemic?. Cureus. 2020; 4: e7538. DOI: 10.7759/cureus.7538.

20. Davidson ED, Proudfoot J, Lee K, et al. A longitudinal analysis of nurse suicide in the United States (2005-2016) with recommendations for action. worldviews Evid Based Nurs. 2020; 17: 6-15. doi: 10.1111/wvn.12419.

21. Wang C, Pan R, Wan X. Immediate psychological responses and associated factors during the initial stage of the 2019 Coronavirus Disease (COVID-19) epidemic among the general population in China. Int. J. Environ. Res. Public Health. 2020; 17: 1729. DOI: 10.3390/ijerph17051729.

22. Tay BYQ, Chew NWS, Lee GKH, et al. Psychological impact of the COVID-19 pandemic on health care workers in Singapore. Ann. Intern. Med. 2020; M20-1083. DOI: 10.7326/M20-1083. 